\title{
The Influence of Using Short Story Toward Students' Vocabulary Mastery at the Seventh Grade Students of An'nur Junior High School Tanah Abang Jakarta Academic Year 2019 - 2020
}

\author{
Ega Dwi Febriyanti ${ }^{1}$, Riandi ${ }^{2}$
}

${ }^{1}$ English Education Study Program of Teacher Training and Education Faculty, Universitas Mathla'ul Anwar Banten 2 English Education Study Program of Teacher Training and Education Faculty, Universitas Mathla'ul Anwar Banten

\section{ARTICLE INFO}

Keywords:

Short Story

Vocabulary

\begin{abstract}
As an International Language, English is important to learn by everyone in the world. The important thing which must mastery when someone learns English is vocabulary. As an important aspect, vocabulary is hard to master because the writing and the pronunciation is different and difficult to memorize. That's why the researcher wants to develop a good teaching and technique to teach vocabulary mastery. The researcher also wants to steal interest of students then remove scared image of learn English using Short Story. Based on the explanation, the researcher purposed to investigate the influence of using short story toward students' vocabulary mastery. The research used a quantitative method with trueexperiment design. The researcher take two sample classes which 7-A as control class and 7$\mathrm{B}$ as experiment class. After tested the validity of the instrument which used for the research, the researcher used 25 numbers of valid questions as the instrument. The researcher gives same pre-test for both of the sample class. Then the researcher gives "The Tortoise and The Hare" short story as treatment to experiment class. In the control class the researcher teach a using poetry "I Follow My Dreams By Delilah". After treatment the researcher also gives both of the sample class same post-test. The test is contained of same question with the pre-test, but the researcher was mess up the number of question. After get the data of the research the researcher also analyzed the data. The result of the data shows the difference of score of the both of sample classes. The researcher found the score of experiment class is better than the control class. That can be seen as T-count $3.3153>\mathrm{T}$-table 1.994. Based on the result of the research data above, Ho is rejected and Ha is accepted. The result also shows the significant increase of the score between pre-test and post-test of experimental class. And not any significant increase on the pre- test and post-test of control

class. That mean, using short story to improved students vocabulary mastery is effective
\end{abstract}

This is an open access article distributed under the terms of the Creative Commons Attribution 4.0 International License, which permits unrestricted use, distribution, and reproduction in any medium, provided the original work is properly cited. @ 2020 Ega Dwi Febriyanti, Riandi

\footnotetext{
1 Corresponding author's address: English Education Study Program of Teacher Training and Education Faculty, Universitas Mathla'ul Anwar, Banten, Indonesia

e-mail: egadwifebriyanti67@gmail.com

2 Corresponding author's address: English Education Study Program of Teacher Training and Education Faculty, Universitas Mathla'ul Anwar, Banten, Indonesia

e-mail: rianriandi87@yahoo.com
} 


\section{INTRODUCTION}

English is the language which have important part in International relationship. Every countries have difference language, every people use it for communication with people from difference country. That's why English become an important language. As a developing country, Indonesia should be able to use English for communication. Teaching English to young learners is very important because it will serve as the main foundation for students to learn English at the higher level. Before mastering English, the main things that must be mastering is vocabulary. However, vocabulary is difficult for most of the students. There are many reasons why vocabularies is difficult to mastery.

The first, English vocabulary is different from Indonesian viewed from form, including pronunciation and spelling, meaning and the word use. Secondly, to mastery English we must read and memorize many words. But, as we know reading and memorizing is bored. The thirdly, the teacher was not real graduates from English Department. Based on these reasons, variations in teaching English are needed. In order to make students interest on reading and memorize vocabulary, it is better to provide teaching aids. For steal students' hearts so they are interest to reading, teacher can use short story as a media.

The researcher choose short story, because it has many various kinds that is fables, folktale, fairy tales, myths and legend. Usually, junior high school students' like a fairy tales. That will attract students' more interested to read. When students read a story that attract them, students can find so many new vocabulary. And that means, the students can develop their vocabulary.

Every people need communication to express their feeling and to express what they think. All of that activity need the words, and these words named vocabulary. As one of the important thing to mastering English, have many vocabulary is a must. When students didn't have many vocabularies, it will give a big barriers when they learn English. Rivers and Nunan (1991 in Alqahtani : 2015) stated: "Furthermore, argue that the acquisition of an adequate vocabulary is essential for successful second language use because without an extensive vocabulary, we will be unable to use the structures and functions we may have learned for comprehensible communication." . That's why every students must read and memorizing many words.

Based on the identification, the researcher try to identification about vocabulary and how to improve student's mastery of vocabulary. It can be seen from the advice that David Wilkins stated that without grammar, it would be very hard to convey, without vocabulary nothing can be conveyed. Studies of incidental vocabulary acquisition in second language learning have gained increasing attention both at home and abroad ( Liu 2015:59 ). Vocabulary acquisition is a necessary part, yet a difficult problem in second language acquisition.

Reading is no stranger again, since start of education world every student was taught to read. Every level of school have difference material to read by their student. Reading is one of important skill, not only for learn English but for many activity. Reading is a receptive skill through it we receive information. Reading as one of the basic language skills has an important role in widening one knowledge to access information and make meaning. For many years, Indonesian government has attempted against literacy by declaring that reading is the solution for broaden knowledge. In other words, the students are expected to get knowledge and understand the context that has been explained in the text. It means that the students need to learn a considerable amount of information from a text.

Short stories tend to be less complex than novels. Usually, a short story will focus on only one incident, has a single plot, a single setting, a limited number of characters, and 
covers a short period of time. In this research, the researcher will use short story to improve student vocabulary mastery, and the researcher would explain more about short story. Short stories can be written in a variety of formats, but the most typical features a small cast of characters with names and focuses on a single, selfcontained incident. Short stories make use of a plot and other normal literary components, just to a lesser and shorter degree than a novel.

\section{METHODOLOGY}

There are some methodologies in writing research paper, and every research has its own research method that is determined based on the purpose of the research. This research was design as a quantitative research. Quantitative research is the methods who use numerical data and emphasize the research process in measuring outcomes aimed at using statistical analysis. In this research, the researcher use true experimental research design. In this study, researchers used Desgin-Posttest Control Group Desgin, where both randomly selected groups were given a pretest and posttest.The nature of the research was comparison of the control class and experiment class.

The researcher asked permission to the school and began an observation on November 11th. Then she started to do the research there. The research start on November 21th up to December 9th for twice meeting in a week, so its total 6 meetings. After doing the research in the classroom, the researcher collected the data, and then the researcher began to analyze them. This research will be implemented at seventh grade students of An'Nur Junior High School in academic year 2019-2020 at Tanah Abang, Jakarta. The school's located is Jl. Ks Tubun Raya 29 Petamburan, Tanah Abang, Central Jakarta - DKI Jakarta 10260, telephone : 021-532-5195.

On a research, population is generally a large collection of individuals or objects that is the main focus of a research. In this research, the researcher took the seventh grade students of An Nur Junior High School in academic year 2019-2020 which who have 143 students from 4 class. A sample is a subset of a population selected to participate in the research. The sample must be representative of the population from which it was drawn and it must have good size to warrant the research. Based on statement above, the researcher took two classes on seventh grade students of An'Nur Junior High School as the sample. These is VII-A class, as a control class which has 36 students and VII-B class as an experiment class which has 36 students. That's mean, the researcher take 72 students for this research.

Every research need a data, and every research have different data and different method to collect the data. In these research, the researcher used test to the students. To get the data before the treatment, the research give pre-test to the both of class (control class and experiment class) and ask them to answer the test. The test that will the researcher give to the both of class is a multiple choice and crossword taken from a short story. After get the score for the students, the researcher give a treatment to the experiment class. In the treatment is give the students in experiment class a short story. The students must underline and find the Indonesian meaning of that words, they can use dictionary or ask the researcher. When they read and find the meaning of some word for more than one time, automatically they will memorize that words. For the control class, the researcher give poetry "I Follow My Dreams By Delilah".

The researcher ask students to read and memorized the vocabulary of the poetry. After giving the treatment, the researcher collect the data again. The researcher give a same test. But in the second test, the research mess up the sequence of the data. In the result, we can see the differences from the score before and after treatment.

To analyze the gathered data, the researcher used statistical composition in calculating the result of the test. Before the researcher analyzing the data using T-test, the researcher also 
calculated the mean of the score from experimental class and control class. And calculated the standard deviation of both of class of students vocabulary mastery by formulas as follows :

1. Mean

Mean is the average value obtained from the sum of all values from each data, then divided by the amount of data available. To Find the Mean of Experiment Class and Control Class, the researcher uses formulas from Abdurahman et al (2011:96) as follow:

$\bar{X}=\frac{\sum x}{N x}$

Where:

$\bar{X}=$ Mean

$\Sigma \quad=$ The sum of the gain result

$\mathrm{N}=$ The number of score

2. Standard Deviation

In statistics, Standard deviation is a measure which used to measure the amount of variation or the distribution of a number of data values. To Find the Standard Deviation of Experiment Class and Control Class, the researcher uses formulas as follow :

$$
\mathrm{SD}=\sqrt{\frac{\sum(x-\overline{x) 2}}{N-1}}
$$

Where :

$\mathrm{SD}=$ Standard Deviation

$\bar{X}=$ Mean

$X=$ The gain result

$\mathrm{N}=$ Number of sample

3. The Homogeneity of The Sample

The homogeneity need to find to measure the sample is homogen or not. The $o$ find the homogeneity of the sample, the researcher used F Test. The researcher also used formula from Sugiyono (2018:199) as follow :

$$
F=\frac{\text { Big Variant }}{\text { Small Variant }}
$$

Where :

If Fcount $<$ Ftable then the variant is homogeneity

If Fcount $>$ Ftable then the variant is not homogeneity

4. Chi Square

According to Sugiyono (2018:172) "Chi Square use to find the normality of the data. If the Chi Square count is smaller or equal to the chi square table $(\mathrm{X} 2<\mathrm{X} 2)$, then the distribution is normal and if greater is not normal". To find the chi square of the data research, the researcher use formula as follow:

$$
X^{2}=\frac{(f o-f h)^{2}}{f h}
$$

Where :

If $\mathrm{X}_{2}<\mathrm{X}_{2}$ count The data is normally distributed

If $X_{2}>X_{2}$ count The data are not normally distributed 
5. Statistic of The Research Hypothesis

In the research, to find the hypothesis result the researcher used T-test to get the differences between two variables. The formula that use is :

a. The Significant Test (T-Test)

According to Sugiyono (2018:196) "If the $\mathrm{n} 1=\mathrm{n} 2$ and the variants is homogeneity, the researcher can find the T-test result used the one of the separated Varian formula or Polled Varian Formula".

b. The Degree of Freedom

The researcher also need to find the result of degree of freedom to seen the total of $\mathrm{T}$ - table (df). Then the $\mathrm{df}$ will be used to compared with the T-Test to determine the results of the study. The researcher use formula from Sugiyono (2018:1996) as follow :

$\mathrm{df}=\left(\mathrm{N}_{\chi}+\mathrm{N}_{\gamma}-2\right)$

Where:

$\mathrm{df}=$ Degree of freedom

$\mathrm{N}_{\chi}=$ The number of experiment class

$\mathrm{N}_{\gamma}=$ The number of control class

Analysis data is the important step on the every research. The effective or not the strategy on the research can be seen in the result of the dataThe researcher calculating the mean, standard deviation, and chi square of Pre-test, Post-Test and the Gain of score from experimental class and control class.

1. Experimental Class

After analyzed and calculated the data of pre-test and post-test of experiment class, the researcher summarized the result into the table bellow :

Table 1.1 The Result of Data Analyzed of Experiment Class

\begin{tabular}{clccc}
\hline No & Specification & Pre-Test & Post-Test & Gain \\
\hline 1 & Mean & 45.17 & 77.06 & 30.50 \\
\hline 2 & Standard Deviation (SD) & 9.09 & 9.86 & 12.82 \\
\hline 3 & Chi Square & 1.28 & 5.28 & 1.32 \\
\hline 4 & Dk of Chi Square & \multicolumn{3}{c}{$(\alpha=0.05) 11.070$} \\
\hline
\end{tabular}

Based on the table above that can be seen where using short story as strategy is give an effective impact and give any significant effect toward students vocabulary mastery.

2. Control Class

After analyzed and calculated the data of pre-test and post-test of experiment class, the researcher summarized the result into the table bellow :

Table 1.2 The Result of Data Analyzed of Control Class

\begin{tabular}{clccc}
\hline No & \multicolumn{1}{c}{ Specification } & Pre-Test & Post-Test & Gain \\
\hline 1 & Mean & 31.60 & 51.47 & 21.40 \\
\hline 2 & Standard Deviation (SD) & 6.88 & 7.45 & 10.10 \\
\hline 3 & Chi Square & 8.68 & 10.60 & 4.58 \\
\hline 4 & Dk of Chi Square & \multicolumn{3}{c}{$(\alpha=0.05) 11.070$} \\
\hline
\end{tabular}


Based on the table of the result from control class, that can be seen where only using book without any strategy for support is didn't give a significant impact for student vocabulary mastery.

\section{DISCUSSION}

After analyzed the data which take from both of the samples class, the researcher found the result. After found the data, the researcher also test the differences of the data used TTest. The discussion as follow :

1. The Significant Test (T-Test)

After analyzed the data used T-test, the researcher found the T-count (result of T-test). The result of T-count will be test with the criteria of significant test : if Tcount $>$ Ttable Ho Rejected and Ha Accepted. So, the T-count 3.3153 > T Table 1.994, that mean is Ho Rejected and Ha Accepted.

2. The Degree of Freedom

After analyzed the data using formula and using T-table, the researcher found the $\mathrm{df}$ of this research is 70. After compared the result of df with T-table, the researcher found that the T-table of the research is 1.994 . Then, the result will input into the criteria of significant test, that is : If T-count > T-table Ho Rejected and Ha accepted. So, the Tcount $3.3153>$ Ttable 1.994, that mean is Ho Rejected and Ha Accepted.

In this research, the researcher discuss about the data analyzes of the data which take from both of Experiment Class and Control Class. After analyze and calculated the data, the researcher also make the conclusion of the data. In the research process, the researcher take two sample class and give both of them same two same test. The first test or the pretest is contain with 25 questions numbers and the second test or the another name is posttest is contain with the same questions with the pre-test. But, in the post-test the researcher mess up the number of the questions.

The role of this research is, after give both of sample class pre-test the researcher also give treatment. The experiment class get a treatment using short story to improve their vocabulary mastery. And the control class get the discussion class using a lesson plan which the researcher get from the English teacher in that school. After finished the research, the researcher analyze the data to find the result of the research. The result of the data analyze of this research, can be seen at the table bellow:

Table 1.3 The Result of Data Analyzed of Experiment Class and Control Class

\begin{tabular}{lcccccc}
\hline \multirow{2}{*}{ Kind of Data } & \multicolumn{3}{c}{ Experimental Group } & \multicolumn{3}{c}{ Control Group } \\
\cline { 2 - 7 } & Pre-Test & Post-Test & Gain & Pre-Test & Post-Test & Gain \\
\hline Mean & 45.17 & 77.06 & 30.50 & 31.60 & 51.47 & 21.40 \\
\hline Standard Deviation (SD) & 9.09 & 9.86 & 12.82 & 6.88 & 7.45 & 10.10 \\
\hline Chi Square & 1.28 & 5.28 & 1.32 & 8.68 & 10.60 & 4.58 \\
\hline Dk of Chi Square & \multicolumn{7}{c}{$(\alpha=0.05) 11.070$} \\
\hline T-Test & \multicolumn{7}{c}{3.3153} \\
\hline Degree of Freedom & $(\mathrm{df}=70 ; \alpha: 0.05)=1.994)$ \\
\hline
\end{tabular}

According to the data above, the researcher found the difference of experiment class and control class. The score of Experiment class is better than the control class. That mean, the strategy of using short story toward vocabulary mastery is effective and can used as a good strategy to teaching learning process.

\section{CONCLUSIONS}

After finishing this research, the researcher analyzes the data and used T-test to find the result of the research and draw some conclusions. Firstly, According to the criteria of significant test : if T- 
count > T-table so Ho Rejected and Ha accepted. Based on the data, the result of T-count is 3.3153 and the degree of freedom (df) is 70 . According on the T-tabel where $70 \mathrm{df}$ is 1.994, and that mean the T-count result is higher than the T-table in term of statistically. That can be seen as T-count $3.3153>$ T-table 1.994. Based on this result of the research data above Ho is rejected and Ha is accepted.

Secondly, after analyzing the data the researcher found there is any significant difference between the experiment class and the control class after have the treated by using short story toward students vocabulary mastery. The mean of the experiment class is higher than that of the control class. That mean, there is significant influence of using short story toward vocabulary mastery. Using short story can develop students' vocabulary mastery. It can be seen on the data result. Where, the score of experiment class increased from1752 in pre-test to 2756 in post-test. And the control class increased from $1398 \mathrm{n}$ pre-test to 1924 in post-test. That can be seen, the experiment class improvement was significant as the control class.

After finished the research, the researcher also release any that this research still need improvement. There are some suggestion about using short story as a strategy to improve students vocabulary mastery, as follow :

1. For The English Teacher

Before uses this strategy, observation of what the genre of short story which students interest is needed to steal the students' attention. And the teacher also needed choose short story which have a simple words.

2. For The Students

The students can used this strategy to improve their vocabulary mastery. They can search what the genre they interest. When the students interest with the story, automatically they will curious about what the meaning of the story and they will try to understand that story.

3. For The Other Researcher

For the other researcher who want to use short story for their research, the researcher suggest to apply on the other skill, like a speaking or another skills. As an important language, English is still difficult to mastery. Many students still think learn about English is very difficult and bored. That's why, for the other researcher still need to find more strategy to steal students' interest in learning.

\section{REFERENCES}

Alizadeh. (2016). Vocabulary Teaching Techniques: A Review of Common Practices. Lahijan. International Journal in Research of English Education.

Alqahtani, Mofareh. 2015. The importance of vocabulary in language learning and how to be taught. International Journal of Teaching and Education.

Andi (2015). The Effectiveness of Skimming - Scanning Strategy In Improving Students' Reading Comprehension At The Second Grade Of Smk Darussalam Makassar. Skripsi pada Prodi Pendidikan Bahasa Inggris FKIP Universitas Makassar: Tidak Diterbitkan.

Aripin, Zainal (2011). Evaluasi Pembelajaran. Bandung: PT Remaja Rosdakarya.

Eka, Tiara (2018). The Use Of Short Story As Materials In Reading Comprehension In Mts Yapi Pakem Sleman Yogyakarta Grade IX. Skripsi pada Prodi Pendidikan Bahasa Inggris FKIPUniversitas Islam Indonesia : Tidak Diterbitkan.

Harras A Kholiq (2014). Hakikat Dan Proses Membaca.. Universitas Terbuka Repository. 
Hernawari (2015). Building Up The Studets' English Vocabulary Trough Fanny Stories At Smp Negeri 2 Duampanua Kab. Pinrang. Skripsi pada Prodi Pendidikan Bahasa Inggris FKIP UINAlauddin Makassar: Tidak Diterbitkan

Kunto, Ari. (2013). Prosedur Penelitian Suatu Pendekatan Praktik. Jakarta. PT. Rineka Cipta.

Kurdiatna, Suaedi. et al. (2016). Pedoman Penulisan Skripsi FKIP. Universitas Mathla'ul Anwar Banten. FKIP Unma Banrten

Liu. (2015). A Review of Effect of Different Tasks on Incidental Vocabulary Acquisition. Nantong. Canadian Center of Science and Education.

Maman, Abdurahman Dr. (2011). Dasar - Dasar Metode Statistik Untuk Penelitian. Bandung: Pustaka

Setia Maskor \& Bahaeuuddin. (2016). Receptive Vocabulary Knowledge or Productive Vocabulary Knowledge in Writing Skill, Which One Important? . Malaysia . International Journal of Academic Research in Business and Social Sciences.

Sabouri. (2016). How Can Students Improve Their Reading Comprehension Skill? . Lahijan . Journal of Studies in Educatio.

Sugiyono. (2017) . Metode Penelitian Kuantitatif, Kualitatif dan RED . Bandung . CV. Alfabeta.

Sutopo. (2018). The Effectiveness of Vocabulary Self-Collection and Word Mapping Strategies for Teaching Vocabulary to Maritime Cadets With High and Low Metacognitive Awareness. English Education Journal. 